Etnográfica

Revista do Centro em Rede de Investigação em

Antropologia

vol. 23 (1) | 2019

Vol. $23(1)$

\title{
"Write your biggest dream on a sheet of paper and burn it": subjectivity and subjectification in becoming Israeli
}

"Escreve o teu maior sonho num papel e queima-o": subjetividade e subjetificação no acesso à cidadania israelita

\section{Miguel Vale de Almeida}

\section{(2) OpenEdition}

\section{Journals}

Electronic version

URL: https://journals.openedition.org/etnografica/6597

DOI: 10.4000/etnografica.6597

ISSN: 2182-2891

\section{Publisher}

Centro em Rede de Investigação em Antropologia

Printed version

Date of publication: 1 February 2019

Number of pages: 241-270

ISSN: 0873-6561

\section{Electronic reference}

Miguel Vale de Almeida, "'Write your biggest dream on a sheet of paper and burn it": subjectivity and subjectification in becoming Israeli", Etnográfica [Online], vol. 23 (1) |2019, Online since 21 March 2019, connection on 19 January 2022. URL: http://journals.openedition.org/etnografica/6597 ; DOI: https://doi.org/10.4000/etnografica.6597

\section{(c) (†) 8}

Etnográfica is licensed under a Creative Commons Attribution-NonCommercial 4.0 International License. 


\section{"Write your biggest dream on a sheet of paper and burn it": subjectivity and subjectification in becoming Israeli}

\section{Miguel Vale de Almeida}

This article focuses on the processes of subjectivity change and subjectification among Brazilian Jews who become citizens of Israel. Global Zionist movements and the State of Israel interpellate their Brazilian and Jewish Diasporic identities, and the process of migration (aliyah) is rooted in diverse motivations, that are further challenged by the political situation in Israel/Palestine. The characteristics of the Jewish Diaspora and of citizenship accession in Israel allow for different ways of looking at contemporary migrations and circulations of people, as well as the way that national and cultural identifications are negotiated between subjects, social context, and the state.

KEYWORDS: Israel/Palestine, Brazilian Jews, Zionism, aliyah, migration, subjectivity and subjectification.

"Escreve o teu maior sonho num papel e queima-o": subjetividade e subjetificação no acesso à cidadania israelita - O artigo foca os processos de mudanças na subjetividade e de subjetificação de judeus brasileiros que acedem à cidadania israelita. Os movimentos sionistas globais e o Estado de Israel interpelam as identidades brasileira e diaspórica, e o processo migratório (aliyah) revela motivações diversas e é desafiado pela situação política em Israel/Palestina. As características da diáspora judaica e do acesso à cidadania em Israel possibilitam novas formas de olhar as circulações contemporâneas e o modo como as identificações nacionais e culturais são negociadas entre sujeitos e Estado.

PALAVRAS-CHAVE: Israel/Palestina, judeus brasileiros, sionismo, aliyah, migrações, circulação, subjetividade, subjetificação.

ALMEIDA, Miguel Vale de (miguelva@gmail.com) - ISCTE - Instituto Universitário de Lisboa, Centro em Rede de Investigação em Antropologia (CRIA-IUL), Portugal. 


\section{INTRODUCTION}

C, a young cook, recently arrived in Israel:

"MVA: What's the Taglit like?

C: It's ten days during which you only sleep two hours each night and visit all possible places in Israel. OK, it's not that big... We had like an Israeli tour guide, she was a Brazilian living in Israel, we had also a Brazilian monitor, an Israeli monitor, and, more or less around mid-stay, a few soldiers so that we would know what it was like to be in the army, there was a lot of - how do you say it? - brainwashing, people saying that living in Israel rocks [laughs].

MVA: They try to convince you to do aliyah?

C: Of course [...] there was an activity in the first night of Taglit. You were to write your biggest dream on a sheet of paper and burn it, we should really concentrate and focus on what we wanted most in life, and then burn it, so that you would compare that with the Holocaust and all that we've been through to get here, and so on. That really did something to me. I went back to Brazil, went back to college but six months later came back in a volunteer program in a special education school in the North, this was like right after the second Lebanon war, the kids were really traumatized and I shared a house with 11 people, it was like a commune, we shared everything... if I were to move to Israel that's how I'd like to live... Then I went back to Brazil with my mind made up, 'I'm going back to college, save some money, and I'll go.' About a month after my return to Brazil my brother died... it was very, very traumatic... it took a while until I realized what was happening... a very complicated year... I wanted to come here as quickly as possible [...]." ${ }^{1}$

$\mathrm{C}$ was no longer living in Israel when this article was written. Neither were a few of my other research collaborators, who either returned to Brazil or moved to a third country. But her statement symbolizes the process of emotional, subjective transformation that pushes Brazilian (and other) Jews towards becoming Israeli. And the fact that she has left also symbolizes the processual and unfinished nature of their Israeliness.

This article is based on several periods of fieldwork in Israel between 2012 and 2014. Interviews were conducted with a network of 30 Brazilian Jews who became citizens of Israel, besides many other non-biographical interviews and contacts with other Israelis and Palestinians. The research collaborators are evenly distributed according to gender. Older generations and younger ones 
are present, although the focus has been on recent migrations. Most come from the Brazilian middle and upper-middle classes and from secularized sectors of the Jewish communities. The group of collaborators was chosen due to my previous knowledge of Brazilian society and culture (Almeida 2004), besides my linguistic proficiency as a Portuguese national. The research is not about the wider topic of Brazilian emigration, nor on the wider topic of Israeli ethnic diversity - but rather about the relationship between changes in subjectivity and the pressures of political-subject making and subjectification - in a unique polity and in the harsh conditions of a dramatic political conflict.

Israel is a particularly good case for analyzing the contradictions and dynamics of nation-state building, especially the role of the state in creating specific types of subjects. Brazilian Jewish migration to Israel, on the other hand, is here seen as a good example of contemporary circulations on a global scale, where access to another nationality is an unevenly distributed opportunity and allows for different types of motivation, from material to symbolic and identity ones. Changes in subjectivity, articulated with processes of subjectification by the state, become clear in the case of Diasporic Jews since the inception of the State of Israel, and are challenged by the ethical dilemmas of the occupation of Palestinian land and the fate of the Palestinian people.

The article focuses on interviews that were just a part of a longer process of fieldwork - the interviews were in fact specific moments of systematization of information otherwise collected in continuous, informal interaction with the interviewees. Interpellated by the Zionist movement, as well as by the State of Israel, my research collaborators demonstrate more varied and complex motivations than just Zionism for doing aliyah, especially in times of wider possibilities of international circulation. ${ }^{2}$ Zionist motivations are also of different kinds and ideological inclinations. Furthermore, life experiences in Israel challenge cultural values and definitions of Brazilianness, Israeliness, Jewishness, and Judaism. And, finally, the local political situation challenges Zionist beliefs among my sample of more secularized and politically liberal research collaborators.

From a more universal and comparative viewpoint, very few polities or societies in the world show, like Israel does, almost to the naked eye and in what we could call an exacerbated form, the workings of processes that social scientists talk about, usually in more abstract ways or resorting to examples of the past: the construction of the nation-state, the imagined community, the creation of political subjects, the forces of ethnicity and religion, the role of gender, sexuality and genealogy in the definition of social boundaries of

2 Aliyah - in Hebrew, הִיְ⿱ -, literally "ascension": the process of accession to Israeli citizenship by Diaspora Jews. The opposite process is yeridah ("descent") and is pejoratively applied to Israelis who leave Israel or give up their aliyah process. 
citizenship inclusion and exclusion, and so on. Furthermore, Israel's state building was sui generis or unique. Not technically a colony or settler state in the strict sense of the term (albeit so in political debates), nor "simply" a geographically embedded nation turned into a state, it was rather the product of both the international reconfiguration of the region on the aftermath of World War I and of the historical anti-Semitism of European societies, later enhanced by the Shoah (Holocaust). Also, the building of the state, as well as its ongoing reproduction, was done in a global, transnational way, targeting (but also in alliance with) the Diaspora, through the action of the state's agencies and the international Zionist organizations - and aliyah is just a process that highlights that. Finally, and most dramatically, the process of the constitution of a land, and then a state, for the Jews as a people, entailed the Palestinian catastrophe, the Naqba, thus initiating a new process of fight for a nation and state building. ${ }^{3}$

It is into this world that my research collaborators decide to move, coming from a well-established nation-state, based on republican universal citizenship, but where they may feel, in some junctures, culturally at odds as a religious, ethnic, or cultural minority. Their subjectivities as Brazilians and Jews often meet the processes of nation- and state-making in Israel, whose agencies engage in my collaborators' subjectification not "just" as Jews, but as Israelis.

Finally, one purpose of this article is to contribute to a much needed anthropological intelligibility of Israeli lives, and not to either the ethical or political justification of the historical, social and political reality there, or to its denunciation. It is the power process involved in the relation between being a subject and being made a subject that is of concern here.

\section{SUBJECTIVITY AND SUBJECTIFICATION}

Following Ortner, I understand subjectivity here to be the "ensemble of modes of perception, affect, thought, desire, fear, and so forth that animate acting subjects" (Ortner 2006: 37), as "the basis of agency," a necessary part of understanding how people (try to) act on the world even as they are acted upon (Ortner 2006: 41). This does not dismiss the Foucauldian notion of political, and often subordinate, "subject positions," but rather focuses on the

3 There has been, in recent years, a resurgence of analyses of Israel as a settler-colonial state. These approaches have expanded the traditional, strict definition of the concept (e.g., by Wolfe 1999) and have allowed for richer comparisons with white-settler societies in the New World. Although the debate on the nature of the Israeli State and the Palestinian situation is not the focus of this article, it would be politically irresponsible not to highlight the settler-colonial approach in the listing of Israel/Palestine specificities. The settler-colonial critique is connected with the most recent proposals for the future of Palestine and Israel, namely around the notion of the "one-state solution." Some fundamental references are Abdo and Yuval-Davis (1995), Pappe (2008, 2012), Veracini (2010) and Hilal (2015). 
formation of subjectivities, "complex structures of thought, feeling, reflection, $[\ldots]$ that make social beings always more than the occupants of particular positions and the holders of particular identities" (Ortner 2006: 46).

Since an approach to issues of subjectivity should not be de-politicized, it is useful to resort to Ong's notion of citizenship as a cultural process of subjectification - in the Foucauldian sense of self-making and being-made by power relations that produce consent (Ong 1996: 737); especially her specification of "cultural citizenship" to refer to "the cultural practices and beliefs produced out of negotiating the often ambivalent and contested relations with the state and its hegemonic forms that establish the criteria of belonging within a national population and territory" (Ong 1996: 738). That is why I will focus on some of my collaborators who feel more deeply the ambivalence of both national identity and cultural subjectivity, and the ambivalence between their progressive ideologies and the reality of the conflict in Israel/Palestine. That is, especially, the case of self-identified "left-wing Zionists" (and, of course, the small minority of non-Zionists).

Furthermore, Fassin (2008) contributes with the notion of "political subjectification" in order to "describe the advent of subjects and subjectivities onto a political scene," alluding also to Althusser's (1976 [1970]: 113, in Fassin 2008: 533) concept of interpellation, since "all ideology interpellates concrete individuals as concrete subjects." This should be refined by Butler's statement that subjectification "consists precisely in this fundamental dependency on a discourse we never choose but that, paradoxically, initiates and sustains our agency" (Butler 1997: 2, in Fassin 2008: 534). Foucault had already underlined the fact that "the state's power $[\ldots]$ is both an individualizing and a totalizing form of power [...] due to the fact that the modern Western state has integrated [...] the pastoral power" (Foucault 1982: 782). Aliyah, the making of a Zionist subject, and absorption after arrival in Israel, are processes permeated by this pastoral power of reconfiguring subjectivity. Finally, this happens under conditions of globalization and transnationalism, with acute symptoms of modernity's main contradictions as well as post-modern perceptions and doubts. ${ }^{4}$ My collaborators were first interpellated as Jews and were made citizens and political subjects of Brazil. But they were further interpellated, as members of a Diaspora, by international Zionist movements and by a process of political re-subjectification by the State of Israel.

I do not subscribe to an individualistic approach that would see subjects as free choosers of their paths. But I would not subscribe either to a deterministic view of discourse as a unidirectional exertion of power or ideology. I believe that my collaborators' stories allow for a subtler and composite 
approach and that the dynamic contradictions between Jewishness, Judaism, Zionism(s), Diaspora, and Israeliness are the right context for demonstrating just that.

\section{THREE CONTRADICTORY DYNAMICS - THEN AND NOW}

The fuzziness between ethnic and religious belonging in the criteria for citizenship accession in Israel - one has to be a Jew - is grounded on a series of what I would like to call "contradictory dynamics." They are properly Western, Modern ones, but unique in their juxtaposition in Israel. Firstly, when Zionism was founded in nineteenth-century Central and Eastern Europe it presented itself as a nationalist movement that proposed an alternative to what was perceived as the failed hopes and attempts at Jewish "integration" in European societies, mainly considering anti-Semitic dispositions, laws, incidents, and pogroms, even before the Shoah. It was presented and felt as a question of finding a land for a people or nation without one. Logically that implied defining the people or nation, an issue that was solved by the genealogical criteria of Jewish identity as ethno-religious. Since genealogical belonging is based on historical narrative (or mythological, albeit perceived as historical by the members of the group), Palestine was construed as the place of origin, thus adding meaning to the claim not just for a territory but also for a homeland (Levy and Weingrod 2005).

This leads us to a second "contradictory dynamic." The nineteenth-century zeitgeist, marked as it was by the political economy of colonialism and the discourse and knowledge of Orientalism (Saïd 1990 [1978]), made possible that what was a project of national emancipation for some became a reality of colonial occupation for others (Zureik 1979). ${ }^{5}$ Although the issue was widely debated by the diverse Zionist factions, in hindsight we can say that they were all imbued with Eurocentric ideas of social evolution and progress, and of the civilizing role of the West. Furthermore, Zionist leaderships were mostly secular, on the aftermath of the Haskalah, an enlightened reform movement that started in the eighteenth century among some European Jewish communities and which called for a more cultural than religious brand of Jewish identity. Its secularism enhanced the Zionists' self-perception of engagement with rationality and "progress."

A third "contradictory dynamic" can be established: besides the colonial and Orientalist proclivities, some Zionist leaderships and movements were undergoing the utopian enthusiasm of the labor and communist movements, thus uniting the national homeland project with one of political-economic emancipation, namely through the idea of fashioning a "new Jew," dedicated 
to manual labor, the collective interest, egalitarianism - albeit in a masculinist fashion - as the overcoming of an introjected self-perception of the Jew as a man of letters, a biblical scholar, a tradesman or a skilled professional. These "ambivalent dynamics" led to the belief - in fact typical of Modern sociologism - that secularization would be the inevitable outcome of the progress of reason, replacing religion, and that the Jews too would replace their religious cement with a national, civic one. However, in the establishment of the State of Israel, Ben Gurion would eventually leave for the rabbinical authorities all power of decision and management of civil matters such as marriage, divorce and, most of all, the definition of Jewishness and, therefore, of the criteria for accession to Israeliness. ${ }^{6}$

These contradictory dynamics were constitutive of the Zionist project for the State of Israel and are also, and still, present in my collaborators' dilemmas, as will be shown by the ethnographic material.

\section{ALIYAH, OR “RETURNING” TO HYPER-LOUD NORMALITY AND HYPER-SILENT ABNORMALITY}

The Law of Return is one of the main pillars in the formation and perpetuation of the State of Israel. It is a source of dispute between Israel and Palestine, as well as between Zionism and anti-Zionism. It stipulates that any Jew is automatically eligible for Israeli citizenship. The process of accession to that citizenship by a non-Israeli Jew is called aliyah. At first look, the criteria for eligibility would seem to be just another instance of the application of the jus sanguinis principle for accession to citizenship in many contemporary nationstates. However, and besides arguments and disputes about the legitimacy, or lack thereof, of the State of Israel, what makes the Israeli case specific is that the criteria for belonging do not distinguish in a clear way genealogical and ethnic criteria from religious ones. We tend to see the former as based on "filiation" (and descent) and the latter as based on "affiliation." This is, of course, not just a specificity of the Israeli polity but also a specificity of the Jewish historical and intercultural experience in the Diaspora, with a long record of contentious identity disputes on the more or less ethnic, national, and/or religious definition of the group (not to mention the infamous "racial" hetero-definitions).

Besides the central question of the unique nature of the State of Israel - as a historical replacement of an Arab and Ottoman social and political landscape

6 On Zionism, see, for a general perspective, Dowty (2008 [2005]), but also Avineri (1981), Smith (1995); and M. Cohen (1992); for an Israeli Left Zionism approach, see Shavit (2014); for an Israeli anti-Zionist and post-Zionist perspective, see Pappe (2014); for a Palestinian perspective, see Saïd (1992 [1979]). 
(to use purposefully as neutral as possible terms) by an Israeli one on the aftermath of the British Mandate in Palestine -, the question of the nature of the state and citizenship poses important challenges. The State of Israel was established following the cultural blueprint of the Modern European model of the nation-state and it founded a Western-style liberal democracy. Even the formation, in the first decades, of a socialist political economy seems to reinforce the Modern, European roots of the Israeli political project. But it was also established as an ethnic state. ${ }^{7}$ Besides the Jewish population, non-Jewish citizens include Arab-Palestinians who stayed in the territory after 1948 (that is, who were not driven out during what has become known in Palestinian national narratives as the Naqba, literally "Catastrophe") as well as a minority of Druze and Bedouin. Since the ethnic criteria of "being a Jew" has very fuzzy borders with religious affiliation; since the latter is defined by genealogy rather than adhesion; and since Jewishness and, therefore, eligibility for citizenship, is defined as tantamount to Judaism by religious officials who resort to religious law (Halakhah), the secular nature of a Modern, European-like nationstate is challenged. Further on we will see how this is very much alive today in the tension between religion and secularism in contemporary Israeli society and among my research collaborators. The unquestioned Jewish definition of Israel has even led Israeli social scientists to coin the peculiarities of the state and society with novel terms, as "ethnic democracy" (Smooha 1997) or "ethnorepublican regime" (Peled 1992), while some, like Yiftachel (1997, 2006), have resorted to the more critical term "ethnocracy."

Aliyah covers different experiential meanings. The outside observer may see it as "migration" but Israelis will clearly distinguish migration - that which is done by non-Jews - from aliyah seen as the exercising of the "right of return." The state's definition of citizenship, based namely on the Law of Return, tends to overlap with the subjects' perceptions of the morality of this very specific type of migration, when compared to correlate phenomena around the world. Furthermore, different aliot (plural for aliyah), in the sense of identifiable migration waves, are part of the state's narrative about the creation of the nation. It is a state of aliot, by aliot - again, an outsider could use the terms "colonization" or "migration" - and the official narrative identifies five waves that built the nation up until the independence in 1948. They were mainly from Russia and Eastern European countries (therefore they were mainly Ashkenazi, that is, Central and Eastern European Jews, as opposed to Sephardi, Jews from the Mediterranean world and originating historically in the Iberian Peninsula).

7 "The Jewish features of Israel include formal legal protection of the Jewishness of the state; [...] the citizenship law and the Law of Return; the legal framework of land ownership and use; the special status of the Rabbinate and of the Zionist agencies in the management of public prerogatives; the ethnic conditionality applied to the draft" (Allegra 2009: 559). 
Post-independence aliot are not narrated in the same way, probably because they do not fit into the narrative of the nation-building pioneers and independence fighters. However, their characteristics are object of dispute around their meaning for the development of the independent state: the influx of Sephardic and, particularly Mizrahi Jews (i.e. "Oriental," from Arab contexts) after the declaration of the State of Israel and the subsequent expulsion from Arab states, the rescue of Ethiopian Jews, or the large-scale post-Perestroika migration from the ex-USSR. The dispute was mainly around perceptions about the capacity of these migrants - or lack thereof - to fit into an already established Israeli ethos and polity marked by Ashkenazi hegemony. These include Orientalist interpretations, fears of religious fundamentalism and class prejudices regarding the Mizrahim; ${ }^{8}$ accusations of corruption, manipulation of Jewish identity in the aliyah process, and criticism of linguistic and cultural isolationism regarding the Russians; and racism regarding the Ethiopians. ${ }^{9}$

Since independence, and leaving aside the main fluxes mentioned in the previous paragraph, Israel has had a constant flux of olim (those who do aliyah) from all over the world, among them Latin-Americans and, among these, Brazilians, in migratory processes that are neither based on flight from persecution, nor large-scale and intensive or promoted by state-sponsored rescue operations and demographic policy decisions, but rather small-scale, localized, family- or individual-level decisions. They arrive in a country that is already constituted as a nation-state, a polity, and a political economy, and which is symbolically important and contended in the international imagination due to the conflict. It is no longer the country of the initial colonization and pioneering efforts, of the fight for independence, or of the mystique of the socialist collective communities known as kibbutzim - although those elements play an important role in the imagination of Israel by the olim I worked with. It is, rather, a context marked simultaneously by a hyper-loud normality and by a hyper-silent abnormality. That is, the normality of a westernized, middle-class lifestyle is emphasized and pursued against the backdrop of an agonizing conflict, and the abnormality of discrimination, occupation and war is thus silenced and made as invisible as possible; the perceived (by a Jew who remains in Israel and does not access the Occupied Territories) "normality"

8 On Ashkenazi hegemony and Sephardim/Mizrahim subalternity, see Shohat (1988) and Smooha and Peres (1975). On ethnicity in Israel in general, see Weingrod (1985). On Ethiopian Jews' absorption, see Ashkenazi and Weingrod (1984). Russians have been the focus of most recent studies on migration to Israel: see Ben-Rafael (1997), Golden (2001), Khazoom (2001), Lerner (2007), LomskyFeder and Rapoport (2001), Tartakovsky (2010).

9 Besides aliyah, Israel has witnessed regular migration, especially of care providers from the Philippines and other Asian countries and, recently, was confronted with an influx of Sudanese and Eritrean refugees, whose treatment (namely in detention centers, and as victims of racist attacks) has been the object of dispute regarding incompliance of human rights' standards. 
of a developed, Western, European-style nation-state where to be a Jew is to be a member of a national majority; and the "abnormality" of six decades of conflict, including the Naqba, the occupation of the West Bank, the expansion of settlements in Palestinian areas, the subaltern citizenship status of Israeli Arabs, the situation in Gaza, or periods of violence and attacks, namely the Intifadas, targeting Jews, whether as military or as civilians.

Finally, contemporary aliot, especially from political contexts such as Brazil and social groups such as urban middle classes, need to be seen in a very different light from early mass aliot, politically motivated or as the result of refuge from persecution. They tell us as much about the process of subjectification by the Zionist movement or the State of Israel as they do about contemporary subjectivity processes in a world of unevenly distributed capacity for circulation and belonging, together with unevenly applied surveillance of borders.

\section{"YOU DON'T LOOK BRAZILIAN": COMPLEX SUBJECTIVITIES, MOTIVATIONS AND EVALUATIONS OF ALIYAH}

Between 80,000 and 100,000 self-identified Jews live in Brazil, mainly in the metropolitan areas of Rio de Janeiro, São Paulo and Porto Alegre. My research collaborators come from families whose ancestors migrated to the country mainly from Eastern Europe (Russia, Ukraine, Lithuania, Poland) and most of them are of Ashkenazi background. In one case - as well as in that of one of my collaborators' husband -, part of the family was Sephardic and came from Lebanon, following the Syrian-Lebanese (mostly Christian) migration to South America. Most migrations took place before World War I and as far back as the late nineteenth century. Family narratives mention pre-Shoah anti-Semitism as the main reason for migration to Brazil. In the case of Porto Alegre, some families trace their arrival back to the Baron de Hirsch's failed attempt to establish Jewish agricultural colonies in the state of Rio Grande do Sul. ${ }^{10}$ Most of my collaborators self-identify - following Brazilian standards - as middle or upper-middle class, with high cultural capital, if not always economic. One can say that my collaborators' ancestors where the "cousins" of those Eastern European Jews who took part in the very first aliot to Palestine or who, at least, witnessed the emergence of the Zionist movement. ${ }^{11}$

Following a standard narrative of Brazilian self-representations of national identity, supposedly as a melting pot of republican universal citizenship where

10 Maurice de Hirsch was a nineteenth-century German-Jewish philanthropist who promoted settlements for Jewish refugees from the Russian Empire.

11 On Brazilian Jewry and Zionism, see Bartel (2010), Falbel (1986), Lesser (1995), Bila Sorj (2008), Bernardo Sorj (2008), Milgram (1995), Grin and Vieira (2004), Grin and Gherman (2013). 
language and culture integrate easily and are easily integrated, ${ }^{12}$ my collaborators reinforce the notion that the most striking characteristic of the local Jewish community is its growing "assimilation." The emic meaning of the term revolves around two symbols: secularization, with dwindling religious practice and observance, especially in public (the use of the kippah by men, for instance); and inter-marriage, meaning the loss of matrilineal descent in the (more common) case of Jewish men marrying non-Jewish women.

The question - in definitions of Jewish identity - of cultural versus religious identity is present. Living in a (Western, for lack of a better word) world where ethnicity is closely and ideally tied to the notion of the nation-state, on the one hand, and in which religion is seen as choice and belief, marked by the adhesion to a congregation, on the other, to be a Jew short-circuits, problematizes and challenges this and, therefore, the subjects' identity narratives. Most of them do not have (or ceased to have after childhood or adolescence) what they would consider an active religious life, but rather say that they follow family identity traditions, manifested in attending the synagogue only on high holidays, in attending the family Pesach seder (Jewish "Easter" family meal), and most do not abide to kashrut (dietary laws).

Although diversity is significant - from family members who were or are atheists, to the odd member who might have joined haredi (ultra-orthodox) movements, or alignment with right or left-wing ideological positions, etc. there is a common discourse about a binding community glue: it is educational (schools), civic (associations), and ethnicity-oriented, as well as marked, as of the late nineteenth century and early twentieth century, by the influence and interpellation of Zionism and, later, by the State of Israel itself. Practically all my collaborators attended what they call "Jewish [private] schools" - whether more religious or more secular and even non-Zionist, as in the case of Yiddish schools (see Himmelfarb and Della Pergola 1989, on Jewish education worldwide). The majority has also been part of what they call "the Youth Movement," meaning the local chapters of the international Zionist organizations and political parties. A, a university student in Jerusalem who had been a youth-movement leader in Brazil:

"MVA: What was specifically Jewish in a non-religious school?

A: I ask myself that today. Maybe... the holidays, not just because we had the day off on a Jewish holiday, but also because there was a whole preparation for the holiday, we learned the stories and traditions of each festive day... Also a focus in Israel and language, at least up until eighth grade, around 15 years old. By the end it was a mere formality, even the parents

12 This is, of course, the hegemonic national representation, contradictory with, for instance, the racial divide in Brazil. See Almeida (2004). 
don't think it is important, they would rather have us learn stuff that is needed to go into college. In our senior year we didn't have anything Jewish at all. We'd learn General History, History of Brazil, History of the Middle East - that was the only way they had of keeping some connection still..."

"The Movements," as they are called, upheld the more explicitly Zionist function. Zionist youth movements can be characterized as organizations that share elements of scouting and political-party youth organizations. They are part of international federations, each connected with a variant of the kibbutz movement and, therefore, with historical political currents and parties in Israel since the period of the British Mandate and even before, namely the political divisions inside the World Zionist Congress. Paramount in Brazil are the religious and orthodox Bnei Akiva; the Habonim Dror (connected with the labor movement and "cultural Judaism"); and Hashomer Hatzair, also tied to socialism but further to the Left than Labor. ${ }^{13}$

One of the main effects of participation in the movements is the creation of a specific cultural or ethnic identity within Brazil and, mostly, the identification with Israel as the place of origin, not - as would happen with other ethnic groups in Brazil - with the countries one's forefathers migrated from. The peculiarity is that Israel is a place of origin in mythical times, more of a place you will "go to" than "go back to" - although the narrative is one of "return." Israel becomes a subjective project. B, who came to Israel in 1977 and has been involved with support work for Latin American olim:

"MVA: Did your Zionist beliefs come more from your family or from the movement?

B: I think the movement... My father transmitted a kind of 'silent' Judaism. At home there was no pressure to be Jewish, or to be Zionist, but he would accept anything that I would bring home. So much so that my brother married a non-Jewish woman and there was no opposition from my father, I was the one who did not like it, he was so liberal that I was the one who was the rebel of the family, thanks to the movement. My madrich, my guide in the movement, he lives here, and I told him once, 'you guys brainwashed me so much that I'm still a Zionist and a socialist today' [laughs].”

How do you "arrive at" a "place of origin"? The movements stimulate and prepare the members for visits to Israel. Usually this consists of up to one year of hachsharah, or preparation. The youths more deeply involved will live in Jerusalem for half a year, learning about leadership and informal education, 
besides Hebrew, Zionism and Jewish history. Upon returning home they may become madrichim, monitors or guides in the movement. There are many other programs available, most of them sponsored by agencies of the State of Israel or global Zionist agencies - stays in kibbutzim, Hebrew courses, volunteer experiences, and so on, besides the possibility of college scholarships. For the last 13 years, Jewish youths in the Diaspora have also been resorting to Taglit, a program set by Taglit-Birthright Israel, an NGO sponsored by private foundations, the government of Israel, the Jewish Agency, and Diaspora communities, with the purpose of promoting educational tours in Israel. Practically all my younger collaborators "did Taglit" for a period of ten days to a fortnight (this article starts with a quote from $\mathrm{C}$ narrating her Taglit experience). The trip is practically cost-free and the youths visit the main tourist-cum-national-identity sites, engage in team-building actions, talk with Israeli Defense Forces' soldiers, and visit kibbutzim. In many cases, the Taglit experience amounts to a moment of epiphany in their narratives of subjective transformation, that moment when the decision to do aliyah started. Youths between 18 and 26 years old and who have never participated in an educational program are eligible, except those who participated in the March for Life program, related to Shoah issues. Often, Taglit resorts to madrichim once they have left the movement and hire them as monitors (on Taglit and tourism, see E. Cohen 2003).

My collaborators' reflection on the process of reconstructing subjectivity is connected to their reflections about their motivations for aliyah. In parallel conversations with people with a certain level of responsibility in the process the head of an NGO that supports Latin American olim, and a Brazilian official at the Jewish Agency in Jerusalem who is responsible for the Latin-American and Iberian aliot - the issue is objectified and simplified in a dichotomy: "ideological" versus "economic" motivations. It involves a value judgment that is much more subtly discoursed by my collaborators, but it is the common moral template. It establishes a difference between generations that corresponds to periods in the narrative of the nation - between the pioneering ${ }^{14}$ period of kibbutz collectivism, physical labor, and sacrifice, and today's migrations, that youth supposedly could as well have done to the US or Europe in the contemporary phase of globalization. Comparing this mindset with my collaborators' narratives, on one end of a spectrum we could place the older generation - in their fifties and sixties - who still live in a kibbutz, namely the Brazilian kibbutz Bror Hail, even though it has been widely privatized and they work in their own free initiative and businesses. On the opposite end, the example of a young woman, a dentist who, in spite of having participated in the movement in Brazil, states that she saw in Israel "an opportunity," and that she does not feel very much involved or integrated into Israeli society, actually having 
done her most to avoid the military draft. Along the spectrum we could place those who participated in the movements in Brazil, who were even leaders and engaged in left-wing politics and left-wing Zionism, and who are mostly pursuing their college or graduate education in Israel, while reflecting about the contradictions and dynamics of the local society and of their own identity. They profit from scholarships that can only be granted if aliyah is made, and they have a discourse that states their growing sense of Israeliness while at the same time keeping ties with Brazil and/or with other Brazilians in Israel. D was at the time working for the Jewish Agency in Jerusalem:

"D: Each case is a case. People want to do aliyah for economic reasons, for ideological reasons, and I can say that today the economic is probably stronger than the ideological... How far does ideology take you? I think it goes just as far as the plate of food, the pocket, and today approximately 50 to 60 percent of Brazilian and South American aliot (maybe from the whole world) are done for economic reasons [...] If you come from the youth movement, then maybe 80 percent for ideology - be it Eretz Israel or kibbutz..." 15

The decision to make aliyah takes into consideration certain limiting factors, such as family relationality; it involves motivations that are not easy to convey to others, such as the desire for personal independence; it is faced with challenges, such as cultural adaptation; and it is not without a plan B, be it a return to the home country or re-migration to a third country.

In most cases, families in Brazil do not stimulate aliyah and actually try to stop it or postpone it. A common narrative, regarding my younger collaborators, involves the parents' wish to have their children finish college education in Brazil without interruptions; the fear of having actual or prospective grandchildren growing up far away; and fear of the danger involved in a region in conflict. Also, all of my younger collaborators avoided doing aliyah at an age when they would still have to do military service in Israel. Most talk positively about the fact of holding two passports, especially the Brazilian one, allowing for the possibility of return to Brazil or re-migration elsewhere, the Brazilian passport thus acquiring, when compared to an Israeli one, an added value, instead of the common situation in the US or Europe where it is the Brazilian passport that may be limiting for migratory-policy reasons - and in this case the Israeli passport allows easier access to both the EU and the US. These strategies are also discoursed emotionally and existentially, around the motifs of saudade (missing home), cultural attachments, desire of cosmopolitanism and travelling, and so on. If arrival in Israel, and the following process of absorption 
and adaptation, is usually seen as positive, as the acquisition of what is perceived as a nationality that was always there waiting for you ("finally living in a society where to be Jewish is the normal thing," as one collaborator said), the olim are still expatriates from another cultural tradition.

The negotiated and transforming subjectivity is better seen in discussions about language and about cultural difficulties. For those who have children, the decision on what language or languages to teach and use is crucial. Everyone fits his or her story into the history of the country, comparing the period in the past when it was strongly expected that one would forget the Portuguese language to become exclusively a speaker of Hebrew, to the contemporary period when there is a growing move towards people researching their roots in the Diaspora. E, a journalist in her mid-thirties:

"E: It's been three weeks now that my children started speaking Hebrew among them, and we just go like 'Whoa, stop, stop, we only get to speak Portuguese here!', and so they start using a Hebrew word here and there, mixing them with Portuguese, as in 'the yeledim at school' and we correct them, 'the children at school', it's an endless job. They haven't been to Brazil since they've learned how to talk, they must go and see that there's a place where everyone speaks that language... [But] I don't see myself as either Israeli or Brazilian, I know this may sound snobbish, but I see myself as a citizen of the world."

In everyday interactions, Brazilian Jews are not subjected, in Israel, to the same type of stereotyping or discrimination as in other countries. Granted, the gendered, preconceived notion about the sensuality of Brazilian women is present. Also, many Israelis travel to Brazil (besides India, the traditional destination, especially Goa) for their post-military service time-out and have absorbed the representations of the easiness and cordiality of Brazilian life (especially through the influence of Brazilian music, quite popular in Israel). ${ }^{16}$ The same goes for samba, soccer and the general, typically Western phantasies about a tropical place - and typical of Brazil's marketing in the global cultural market at least since the post-World War II years. But Brazilians are a minority among Latin-Americans in Israel, who are mostly Spanish speakers (mainly from Argentina), and their mostly Ashkenazi ancestry and their middle-class origin prevent the processes of racism and classism that most non-Jewish Brazilian immigrants are victims of elsewhere (and that could

16 On the institution of post-military service travelling in Israel, see Noy and Cohen (2005). Concomitantly, on Israeli emigration, see Shokeid (1988). On the role of the military in shaping Israelis' lives and Israeli culture of militarization as an ethos, see Ben-Ari (1998). In this dossier in Etnográfica, see Gristina's article. 
happen in Israel too, considering the complaints of discrimination of Ethiopian Jews by anti-racism NGOs). Two single young women who have been in Israel for a handful of years:

“F: I get a lot of 'you don't look Brazilian' because I'm very white, that's what they mean, I had a friend who is black, she was a co-worker of mine and she would say 'everyone thinks I'm Latin-American, everyone.'

G: Yeah, because they're expecting people with darker skin, but if you explain that you're Jewish, that my grandparents came from Poland... after all we are Brazilian Jews, the origins are the same as the origins of people here..." 17

Besides the perceptions of "race" and ethnicity by Israelis, and as young women who want to start over their romantic lives, having left behind either family control or emotional debacles, F and G speculate a lot about local cultural codes of courting and sexuality, especially during the initial period of absorption:

"F: Because, you now, suddenly you're living like a teenager...

G: Yeah, the American scene, young people, everyone goes with everyone...

F: And all the gossip... The whole klitah [absorption] thing, absorption into another culture, you don't know how that works, how flirting works, how hooking up works, like, the first guy I went out with, do you remember?, I don't think you met him, but I met him at the bar, he was X's friend, he took me out for dinner in a restaurant!

G: A date! ${ }^{18}$

F: But I don't do dates! You hook up with someone and that's it. Dating means serious business here...

G: Even today I'm like, WTF?, now and then there's a guy who wants to 'date' and there we go, the whole tiring process of dinner and what not...

F: But it's a whole learning process that the Jewish Agency does not explain to you [laughs]."

$\mathrm{H}$, on the other hand, has further expectations about positive developments in Israel in what regards her emotional life:

"H: The only thing missing is a husband [laughs]. I got married in 2002 and six months later we broke up [...] My husband had an affair with his

17 G. is, of course, unreflectively reproducing an Ashkenazi-centered view.

18 The dating system is not a regular part of Brazilian romantic culture. It sounds culturally alien to people used to meeting their love partners in informal situations. 
best friend's wife, who happened to be my best friend. [...] When I got here I faced the problem that there is no religious divorce. The Brazilian divorce was not recognized here (I had a Jewish wedding, but legally it is the civil wedding that counts there). I wouldn't be able to marry again... So I went to the Rabbinate and they told me that the Rabbi in Brazil would have to agree. He contacted my husband, to see if he would agree, which he did, and so I went to Jerusalem to get my divorce certificate. I dressed really conservative and had to face seven rabbis. Since my husband was not there, of course, one of the rabbis represented him. During the ceremony one of the rabbis reads, he asks you to repeat after him, he holds a paper, takes the rings off, opens the hands, drops the paper in them and walks to the door, pretending. Then he comes back and says, 'If he comes to Israel he cannot stay at your house. And you can only marry again in 92 days.'”

The main complaint about interactions is about what they call the Israeli "rudeness," a type of straightforwardness that is easily taken as an offensive way of addressing and arguing. The Brazilians immediately mobilize the stereotypical Brazilian self-perceptions of kindness and cordiality, encapsulated in the gesture of smiling and engaging in interactions that resort to the codes of friendship. But the work ethic, the effort and hours invested in work, connected with the cost of living, the dreariness of housing and its cost, when compared to the large upper-middle-class apartments in Brazil and the availability of domestic help there, are also the political-economic side of the culturalist complaint.

These evaluations are compensated by a change in the way that Brazil is seen, especially during occasional visits, usually once a year for a vacation period. Coming back from those visits, most feel ambivalent. They will romanticize the re-encounter with people, landscapes, climate, or food, but will also criticize the lack of punctuality, the work ethic that is too permeated by improvisation, friendship and the exchange of favors, as well as social inequality, hierarchy, and status anxiety. I, a scientist in her late thirties, who came to Israel mostly for a career opportunity:

"I: When I first arrived I would go to the supermarket, I would smile to the employee, I would do the same at the bank, but I would just get a very dry 'good morning' in return. I was shocked, 'what's wrong with these people? Smile, it's not hard!' People would say, 'oh, you must understand, Israelis have suffered a lot' and I would say, 'no, stop, I know that, because of the wars, but a favela dweller in Brazil, a domestic helper who works and works and works and who doesn't have enough to feed her children, she'll smile...' I now go to this specific supermarket because there's an Ethiopian there who did his Ulpan [Hebrew language course] with Brazilians and he always smiles!" 
Most of all, however, all of my collaborators mention the feeling of safety in Israel when compared to Brazil. Only the fact that I know Brazil quite well, from previous research in that country, allowed me to understand what would otherwise seem an odd or even ethically dubious statement, considering the security issues in Israel/Palestine and the plight of Palestinians. Living in Israel, not in the West Bank or Gaza, and in the less violent years - in Israel - after the second Intifada (roughly, after 2005), they are referring to street safety, thanks to militarization and what has been described as an apartheid between Israel proper and the Palestinian territories, and are comparing it with levels of crime - social crime, not political violence - in Brazil, no matter how much those are based on fact and experience or on perceptions of insecurity.

Evaluations of success and failure in adaptation, identity transformation and future plans are closely connected with motivations for aliyah, which are somehow reconstructed in a contemporary, post-aliyah narrative. All are the product of a dialogue between representations of Brazil as a culture and as a personal relational experience; representations of Jewish identity in Brazil; the role of Israel in the Jewish Diaspora and the promotional actions of the Zionist movements, the State of Israel and the agencies common to both; political-economic aspects; and the confrontation with the Israeli context, including the Israeli-Palestinian conflict.

"B: There was a... huh... traumatic family factor that led me, as a young person, to look for new horizons and come to Israel, because, since I was involved in Zionism, Israel was the obvious choice. For me it was a family trauma: my father was rich, back in the fifties, he had a furniture factory, and he was very well known in the community. But then the business went bankrupt and the Jewish community shunned him [...] I saw it in my father, the way he looked down, humiliated by the community, I grew up with that trauma, and angry about it."

Still today, decades later (she is one of my oldest collaborators and did her aliyah in 1977; differently from the other collaborators, she is the only one not to keep close contact with Brazil), B systematically compares Israel and Brazil on the basis of that experience and praises Israeli egalitarianism and pioneer spirit, while criticizing Brazilian status-oriented culture. She went back to Brazil in 2007 and was invited to give a lecture at her city's B'nai Brit ${ }^{19}$ and was delighted to take her "revenge," to show her success and say that she was her shunned father's daughter. J and $\mathrm{K}$, a woman and a man from the older generation of kibbutz pioneers:

19 Literally "Children of the Covenant," one of the oldest international Jewish organizations, providing social and community support. 
“J: My mother's family was from Russia and my father's from Poland, my grandparents went to Brazil before World War II. We moved to Israel as a family. My father had a bag factory that went bankrupt and he wanted to start over from scratch. My mother actually didn't want to stay in Brazil because she felt ashamed; it was very traumatic to be in the community. This was in 1971, I was 15 years old. My married sisters didn't come along. It was a non-Zionist migration. When we arrived I went to Bror Hail, my father's sister was there, and my parents stayed in the city. It was traumatic, they shoved me in a taxi and I felt like I was being disposed of. Today I know that was what saved me, because I did everything there - language, army. Kids then still lived apart and my aunt and uncle played my parents' role. I felt good and Israeli for the first time when a boy said he wanted to be my boyfriend. An Israeli boy."

J was interviewed, together with others, at kibbutz Bror Hail, where she still lives. K, for instance, was part of the movement in Brazil and of the building of that kibbutz. Political and economic changes in Israel are patent in K's account of how the socialist-Zionist pioneering spirit was challenged and overthrown with the political and economic changes that started in the seventies and moved the country to the right of the political spectrum and towards neoliberal economics:

"K: Life changed, we changed the life concept we had, what we thought changed with time, the kibbutz changed, today it is no longer a kibbutz like before, today it is totally privatized - all means of production belong to the kibbutz but any member, any haver [literally 'friend', a kibbutz member] can work outside, start his own business, like I did, like X and Y [another couple in the kibbutz] have, like J does..."

Similarly to J, a university student, L, came along with her parents who migrated for non-Zionist reasons:

"L [in an interview where F was also present]: Ken [yes], I remember. My mother and her instinct... [laughs]... 'I want my daughters to marry a Jew' [laughs], that was her major concern, not that Jewish men were lacking in São Paulo or that we were in marrying age, but still... But I won't deny it, there were economic reasons, my father was unemployed and thought that living here was a valid option.

MVA: Twenty years ago, 1994, not the Real Plan, right?

F: The Real plan was 1991-92. Collor in 1989, the crisis, the freezing of savings... 
L: Yes, but that wasn't it... The reason for aliyah was China's rising [laughs], because my father made umbrellas and when people started buying Chinese umbrellas there was no more work for him."

\section{CHALLENGED SUBJECTIFICATION, OR "COUNTRIES ARE LIKE METAPHORS ENVELOPED IN IDEOLOGY"}

Aliyah can be seen as a process of change in subjectivity. That is actually how my collaborators see it. But it is also a process of creation of new political subjects, no longer just Brazilian and/or Diaspora Jewish, but rather interpellated by Zionism and by an already established state that sees all Jews as rightful potential citizens and relates to them as objects of its policies of membership recruitment (see Dominguez 1989). Once aliyah is initiated, ${ }^{20}$ "absorption" is the word used to describe the process of language and cultural learning that olim undergo, promoted by the Ministry of Absorption (that, upon arrival, takes over the responsibility for the olim from the Jewish Agency) and that is epitomized in the Ulpan, the language course that, for the younger arrivals who have previously participated in Zionist programs like Taglit, is tantamount to a full immersion summer camp. Especially young and single olim share the absorption center with people from other nationalities. There is a purposeful and acknowledged process of promoting change in subjective identity, ensuring that Jewishness is tantamount to Zionism and to becoming Israeli. ${ }^{21}$

$\mathrm{M}$, who nowadays has started a sports program to integrate Jewish and Palestinian children, has a peculiar life story. He was brought up in a religious framework in Rio but became a left-wing militant there and, later, a left-wing Zionist:

"M: That was always a complicated personal question. The issue of Zionism, that is. Ever since I was a kid I had a problem with the State of Israel. It became clear that it was because of the Palestinian question but, on the other hand, I had never debated the issue deeply, it took many years for

20 Candidates apply for citizenship at the Jewish Agency delegations or online; once their Jewishness is proved (with relevant documents, genealogical and/or religious), the Agency covers travelling expenses. Upon arrival in Israel, the olim are given their Israeli passport. If they want, they can reside for up to a period of a few months in an absorption center to undergo intensive Ulpan (Hebrew language course). Upon arrival in Israel the Ministry of Absorption is responsible for them. It grants them a small stipendium and once the Ulpan is over, they are regarded as regular citizens, having to look for their own housing and employment. Many people do not go through absorption centers, especially if they have relatives and friends ready to host them.

21 On Ulpan and language learning, see Ben-Rafael and Gajst (1993), Katz (1982), Doleve-Gandelman (1989). Eisenstadt (1953, 1954) provides a classical account in Israeli sociology that focused on migration and ethnic diversity, much criticized by contemporary social sciences in Israel (see Bernstein 1980; Cohen, Ifergan and Cohen 2002; Kimmerling 2008). 
me to do so. When I was a left-wing militant I didn't discuss it, I didn't see people discussing it. Whenever there was a student union congress there was always a banner saying 'End the Zionist occupation of Palestine!,' but neither the others nor I knew what that really meant. Today I do, but the others still don't. It was never one issue in militancy, that was much later, when I decided to face it and it was also a question of my Jewish identity, the national question and such... Because until then I think I denied my Jewish identity because I did not know what it was. I studied for nine years in an ultra-orthodox school in Rio, I went to synagogue every day, I studied the Torah, but when I left school and went to college I started to think, 'wait, that has nothing to do with me and if that is what being Jewish is all about, then something is wrong,' you see? How do I fit in this? That's when I started discussing the conflict and understanding the issue of Jewish identity as a national identity, from the other end, not the religious end. But it was clear to me that you go on a Taglit, you only go to the nice places in Israel, the old city in Jerusalem, we visited the University here, we go to tourist spots, we go to the beach, it was like a couple of weeks of nice tourism. But then the issues of the Middle East were very dear to me, the Israeli-Palestinian conflict, and I said to myself, 'If I want to solve this in me I have to live here.' If I hadn't come I would still today be asking whether I am a Jew or not, what it is to be a Jew. It was a rational thing, really. On Yom Hazikaron ${ }^{22}$ we remember the soldiers who died in the wars and the victims of terrorism, and on that day I went to this event by a movement, in Tel Aviv, a Palestinian and Israeli event. It was very cool. An Israeli girl went on stage and told her story, she came from a Yemeni Arab family, and it was always very complicated for her, her family's political ideas were always very right-wing, against the Arabs, but then she changed, and joined that movement; then a Palestinian woman came up and told her story, and so on, one Israeli, one Palestinian, it was not just remembrance of Israeli victims, but also Palestinian. Thanks to the intermediation of Meretz MKs, ${ }^{23}$ the movement managed to obtain authorization to bring 40 Palestinians from the Occupied Territories, who can't enter Israel, it was very cool, there was even one guy who said that his issue was not personal, his daughter had been killed in a bus explosion, he was Jewish, his daughter died but he was saying that he supported a Palestinian State and then a Palestinian guy came along and said that his daughter had been killed by an Israeli soldier, shot in the head at ten meters, and still he did not see the Jews, the Israelis, as a whole, and there

22 Calendar and holidays are crucial elements in the creation of a sense of national and secular culture in Israel. On that, see Handelman and Katz (1990), Dominguez (1989), Zerubavel (1995). For a more critical or radical critique, see Sand (2009, 2012).

23 Meretz is a Left Zionist party. MK means Member of the Knesset (the Parliament). 
were more than 2,500 people there. Outside, a group of Israeli right-wingers yelling that we had no place in Israel, and that we should leave..."

Another collaborator, N, a musician in a Brazilian band, talked extensively about how important it was for him to join a tour of Hebron by Breaking the Silence, and how it shocked him to see the tomb of Baruch Goldstein praised as a saint for having killed 29 people. ${ }^{24} \mathrm{Y}$, on the other hand, a philosophy student from São Paulo, grandson of a rabbi and member of the youth movement Habonim Dror, says that he feels he is a Jew and that is why he wants to be in Israel. But it was only in Israel that he discovered that, "like they say of New York, I love it but it's killing me," and - resorting to his philosophy references - that Rancière's conflict of homonyms applies for the pair "Jews" and "Judaism." In Brazil, Zionism and the Left went naturally together for him, but he doesn't feel it anymore here and "the axioms ceased to be absolute, being a Jew and being here don't go anymore together without an explanation - a consensus has turned into a dissensus," he said, invoking his philosophical preferences again. Many Israelis have been leaving Israel and ask olim why they come here, he mentioned, following a comment on how during the 2014 Gaza war he felt a growing atmosphere of persecution against people in the Left.

$\mathrm{P}$, in her fifties, proudly says that she is a left-winger but that it isn't easy. Her eldest son joined the army during the first Lebanon war, and he actually wanted to be in the front. They fought about it. She started attending mothers' demonstrations against the war and her son asked her to stop, so they fought even more. Her daughter was to join the artillery later on, but "knew the war through vision, since she was in the South working in video productions for the army." However, both children became left-wingers once they left the army and the war experiences. The feeling of hopelessness is also present in $\mathrm{P}$ - for her, "hope was killed in 1995 with Rabin's assassination and this year I sadly realized that I went alone to the celebrations [in memory of Rabin]..."

Also from an older generation, Q left Israel in 1987 for political reasons, during the first Intifada. The trigger was an episode of attack on an Arab citizen by a Jew, something that functioned as a reverse epiphany. She had arrived in 1969, at 13. Later she lived for 10 years in the USA and 16 in Germany. At the time of fieldwork, she had been back for two months. A difficult decision, since she was aware of the fact that her taxes finance illegal settlements, but realized that she wants to grow old here, with welfare support and a better climate.

24 Breaking the Silence is an NGO of Israeli veterans and soldiers that denounces military actions and human rights' violations in the Occupied Territories. Baruch Goldstein was an Israeli religious extremist who in 1994 killed 29 Muslim worshippers. 
T, a PhD student, is P's son. He connects his experience in the war and his denial of it later on, with his mother's history and national origin and his discovery of his Brazilian roots. It took P 17 years until she went back to Brazil for the first time, due to the dictatorship there. When T was 15 he started to feel curious about his family's history. His parents' generation was marked by the ideology of the melting pot, the Zionist idea that everyone should create a common identity, mainly through the re-invented, modernized Hebrew language. The state was incredibly active in promoting this from the onset, subjectifying people linguistically. Part of the process was neglecting roots and origins. But after the seventies and eighties, coinciding with the major shift from Labor hegemony to Likud's (the right-wing party, supported mostly by the growing, largely disenfranchised Mizrahim population), change started. Economic shifts, then cultural shifts - and later, after Netanyahu's second government in 2009, a right-wing hegemony. "People search their roots, and I was touched by that spirit." He started researching when his colleagues in high school started calling him "the Brazilian." He now speaks Portuguese, and has travelled extensively throughout Brazil. His disappointment with Israeli politics - and with the war he was a soldier in - led him to a search of his Brazilianness.

$\mathrm{R}$ is a psychologist and therapist. He knows that aliyah is not just ideological, that for most people there is also an economic factor, a safety factor and, mostly, a family or emotional factor. It is quite common among olim to evade family conflicts, to cut the ties of dependence with parents, to evade love frustrations. Those are the triggers and that is reflected in therapy. "Countries are like metaphors enveloped in ideology," he said. He himself came as a Zionist but doesn't consider himself as one today. He wouldn't go back to Brazil, but not for ideological reasons. Family distance helped him grow and he says: "I recovered my subjectivity through aliyah and separation from my parents." He had been secretary-general of Dror Habonim in Porto Alegre. He arrived in 1987 when the first Intifada started. He remembers watching on TV soldiers firing on demonstrations, and funerals of Palestinians with thousands crying "Death to Israel." "What am I doing here?," he asked himself. He realized he was not just for peace; he was against the right-wing governments. He voted Avodah (Labor), then Meretz, then Hadash (the Arab and Jewish party originating in the Communist party) in the last two elections. "Many Brazilians went the other way, of course, becoming more conservative, even professional Arab-haters." 25 The 2014 war on Gaza was "for me, the last brick of Zionism that fell."

25 Besides my sample of informants, I have followed online support groups for Brazilian olim. They reflect a large lower-middle-class group with conservative political views and lives of "hyper-loud normality" that place Palestinians literally on an unseen "other side of the wall" not dissimilar to attitudes in Brazil towards Blacks. 
There is also the possibility of denying the problems, through hedonism, as is visible in Tel Aviv's bubble ${ }^{26}$ or by overcoming, in a New Age spirit, the concerns of this world. For instance, S, a non-Jewish Brazilian married to an Israeli Jew, says that her husband was very left-wing and political. At a certain juncture in their marriage they decided to join a group of alternative friends who lived in an eco-village. They "discovered another path": "We found out that to be political is to be nervous, sad, and hysterical. We don't watch the news anymore and are much more tranquil now. We don't want to know."

But the hyper-silent abnormality that I referred to previously surfaces, and breaks the hyper-loud normality of Tel-Aviv's bubble, in my collaborator and friend U's statements, especially one late afternoon when we took a long walk from Tel-Aviv to Jaffa. ${ }^{27}$ "I never wanted to be Israeli," she says. "I came to Israel in 1969, but I've never wanted anything other than to be Brazilian and I have remained Brazilian. I never wanted to look or sound Israeli. My accent hasn't changed, I have a strong Brazilian accent, and yet I've been here for 44 years now, never tried to change it. It was always very clear to me that I am not from here."

$\mathrm{U}$ was never involved with Zionism. Her parents sent her to Israel as a teenager, as a pedagogical gesture, to study in a boarding school. She was to become a journalist, always as a correspondent for foreign presses, namely Brazilian. She developed into a very critical person, politically, of Israeli society and is a staunch supporter of Palestinian rights. Walking with her in the HaTachana area in Tel Aviv, where the old Ottoman train station for Jaffa has been converted into a trendy shopping mall, she mentions how most people don't even know what was there before. The same applies to the boardwalk connecting Tel-Aviv to Jaffa, which we walked along afterwards. "People don't know that it was all destroyed and leveled. I remember walking here, through ruins, and seeing books on the ground, children's toys, china, from Palestinian homes." And then she shows me the Museum of Etzel, dedicated to the "liberation of Jaffa." It is a glass structure juxtaposed on the remains of the stone structure of an old aristocratic Palestinian house. The sense of absence or removal of Palestinians becomes present, as does the sense that in Palestinian towns and neighborhoods in Israel or beyond the border or in the Diaspora, there is a silenced (for my collaborators and myself in Israel) narrative of return, of longing, of loss,

26 "The bubble" is a common Israeli popular culture trope describing Tel-Aviv's hedonistic lifestyle, as opposed to Jerusalem's tense political and religious life, as well as life in the Occupied Territories and Gaza. It has been portrayed in media products such as Eytan Fox's 2006 film The Bubble.

27 Jaffa is the centuries-old port capital of Palestine. It is now integrated in the Tel-Aviv/Yaffo (Jaffa) metropolitan area. Tel-Aviv was built from scratch in the early twentieth century in a swamp area next to Jaffa. 
of Naqba..$^{28}$ Walking further down to the Arab section of Jaffa, to eat in a restaurant that was rebuilt after a bombing by a right-wing radical Jew, she remembers meeting a couple of Orthodox Jews from the state of Pará, in the Brazilian Amazon. She met them in a bus, in the West Bank. They had lived in Jerusalem but, since it was too expensive there, they had moved to a settlement near Jericho, in the West Bank. They were telling her how beautiful it was there and $U$ asked them nonchalantly, "What about the Arabs?," to which they replied, "But are there any Arabs in Jericho?" (see Flint and Sorj 2000; Flint 2009). ${ }^{29}$

\section{CONCLUDING REMARKS, OR “WRITE YOUR BIGGEST DREAM ON A SHEET OF PAPER AND BURN IT" ONCE MORE}

As stated by Butler (2012), following and elaborating on Arendt (1951), Jewishness is not tantamount to Judaism and neither of them is tantamount to Zionism. Zionism itself comes in different shades of ideology, politics, and subjective feeling. For many of my collaborators, Zionism merely describes a feeling of belonging to a nation-state where Jewish identity is tantamount to an ethnic-national feeling. For others it is politically and ideologically problematized, whether positively or negatively, and even challenged by the reality of the State of Israel, the occupation, and the asymmetrical conflict over land and sovereignty between the State of Israel and the Palestinian population, whether inside the State, in the West Bank and Gaza, or in refuge, exile and the Diaspora. Furthermore, Israeliness has established itself as a national identity that is in part culturally alien to Diasporic Jews.

The creation of the State of Israel has, however, fundamentally changed the connections between these concepts and identities. The Zionist movements and agencies, and the State of Israel are important actors in Diasporic Jewish subjectivities and life projects. Motivations for aliyah - when it is considered as a possible project - can be multiple and contradictory, as life experience in Israel can be ambiguous. Exposure to cultural difference, in a consolidated nation-state, stimulates the differentiation between Brazilianness and Israeliness, thus reconfiguring notions of Jewishness and Judaism too. This can be further enhanced by the ethical and political experience of exposure to both the social inequalities in Israel, and the conflict and the Palestinian situation. My collaborators' subjectivity as Jews - whether "culturally" or "religiously" - and as Brazilians is further challenged by Zionism and by Israel, whose agencies

28 On the longing for return among Palestinians, see Kuzar (2008); on separation and, as some say, apartheid between Jewish and Arab Israelis, see Rabinowitz (1997); on Naqba landscapes, see Stein (2010).

29 U passed away when this article was being written. She went back to Brazil to die. I dedicate this article to her. 
stimulate processes of subjectification. This is not a one-way street, not in the conditions of global circulation for those empowered to enjoy them.

As I write these final words, I have become aware of the fact that some of my collaborators have left Israel ever since fieldwork, as did C, quoted in the beginning. They have either gone back to Brazil or to third countries, following personal, emotional or professional projects and opportunities or escaping similar difficulties in Israel. Others have stayed and even deepened their roots or become committed to political change. In some cases, the 2014 Gaza war was the triggering factor, or the turning point that is symbolically elaborated to justify doing yeridah - "descent" -, the opposite of aliyah. Others, while knowing that they may always have a plan B that many sabra (native Israelis) don't have, remain attached to what they consider to be their rightful land.

I can only hope that I was fair in conveying their multiple meanings and in providing some intelligibility to a context that, even in anthropology, is too much a hostage of an incapacity or unwillingness to see and hear concrete, real persons before judging - and that independently of the merit and ethical imperative of portraying, as most ethnographies of the region have rightfully done, the experience of oppression of the Palestinians. Furthermore, this specific case may contribute, through the ethnographic vignettes shown, ${ }^{30}$ to a better understanding of how inseparable processes of subjectivity and subjectification (especially by the state) are, operating through idioms of cultural identification. 


\section{REFERENCES}

ABDO, Nahlo, and Nira YUVAL-DAVIS, 1995, "Palestine, Israel and the Zionist settler project”, in D. Stasiulis and N. Yuval-Davis (eds.), Unsettling Settler Societies: Articulations of Gender, Race, Ethnicity and Class. London, Sage, 291-322.

ALlEGRA, Marco, 2009, "Citizenship in Palestine: a fractured geography", Citizenship Studies, 13 (6): 553-573.

ALMEIDA, Miguel Vale de, 2004, An Earth-Colored Sea: "Race", Culture and the Politics of Identity in the Post-Colonial Portuguese-Speaking World. Oxford and New York, Berghahn Books.

ALTHUSSER, Louis, 1976 [1970], "Idéologie et appareils idéologiques d'Etat", in L. Althusser, Positions (1964-1975). Paris, Editions Sociales, 67-125.

ARENDT, Hannah, 1951, The Origins of Totalitarianism. New York, Harcourt, Brace and Co. ASHKENAZI, Michael, and Alex WEINGROD, 1984, Ethiopian Immigrants in Beersheva: An Anthropological Study of the Absorption Process. Highland Park, IL, American Association for Ethiopian Jews.

AVINERI, Shlomo, 1981, The Making of Modern Zionism: The Intellectual Origins of the Jewish State. London, Weidenfeld and Nicholson.

BARTEL, Carlos Eduardo, 2010, "Sionismo e progressismo: dois projetos para o judaísmo brasileiro", WebMosaica: Revista do Instituto Cultural Judaico Marc Chagall, 2 (2): 83-95.

BEN-ARI, Eyal, 1998, Mastering Soldiers: Conflict, Emotions, and the Enemy in an Israeli Military Unit. Oxford, Berghahn.

BEN-RAFAEL, Eliezer, 1997, "Identity and language: the social insertion of Soviet Jews in Israel”, in Noah Lewin-Epstein, Yaacov Ro'I and Paul Ritterband (eds.), Russian Jews in Three Continents: Migration and Resettlement. London, Frank Cass, 364-388.

BEN-RAFAEL, Eliezer, and Idit GAJST, 1993, The Role of the Ulpan in Immigrant Absorption: Russian and English Speakers. Tel Aviv, Institute for Social Research [in Hebrew].

BERNSTEIN, Deborah, 1980, "Immigrants and society: a critical view of the dominant school of Israeli sociology”, British Journal of Sociology, 31 (2): 246-264.

BUTLER, Judith, 1997, The Psychic Life of Power: Theories in Subjection. Stanford, Stanford University Press.

BUTLER, Judith, 2012, Parting Ways: Jewishness and the Critique of Zionism. New York, Columbia University Press.

COHEN, Erik, 2003, "Tourism and religion: a case study - visiting students in Israeli universities", Journal of Travel Research, 42: 36-47.

COHEN, Erik, Maurice IFERGAN, and Eynath COHEN, 2002, "A new paradigm in guiding: the Madrich as a role model", Annals of Tourism Research, 29 (4): 919-932.

COHEN, Mitchell, 1992, Zion and State: Nation, Class, and the Shaping of Modern Israel. New York, Columbia University Press.

DOLEVE-GANDELMAN, Tsili, 1989, “Ulpan is not Berlitz': adult education and the Ethiopian Jews in Israel”, Social Science Information, 28: 121-144.

DOMingueZ, Virginia R., 1989, People as Subject, People as Object: Selfhood in Contemporary Israel. Madison, University of Wisconsin Press.

DOWTY, Alan, 2008 [2005], Israel/Palestine. London, Polity.

EISENSTADT, S.N., 1953, "Analysis of patterns of immigration and absorption of immigrants", Population Studies, 7: 167-80. 
EISENSTADT, S. N., 1954, The Absorption of Immigrants. London, Routledge and Kegan Paul. FALBEL, Nachman, 1986, "Early Zionism in Brazil: the founding years, 1913-1922", American Jewish Archives, 38 (2): 123-136.

FASSIN, Didier, 2008, "The humanitarian politics of testimony: subjectification through trauma in the Israeli-Palestinian conflict", Cultural Anthropology, 23 (3): 531-558.

FLINT, Guila, 2009, Miragem de Paz: Israel e Palestina, Processos e Retrocessos. Rio de Janeiro, Civilização Brasileira.

FLINT, Guila, and Bila SORJ, 2000, Israel, Terra em Transe: Democracia ou Teocracia? Rio de Janeiro, Civilização Brasileira.

FOSTER, Robert J., 1991, "Making national cultures in the global ecumene", Annual Review of Anthropology, 20: 235-260.

FOUCAULT, Michel, 1982, “The subject and power”, Critical Inquiry, 8 (4): 777-795.

GLICK-SCHILLER, Nina, Linda BASCH, and Cristina SZANTON BLANC, 1992, "Transnationalism: a new analytic framework for understanding migration”, in Nina Glick Schiller, Linda Basch and Cristina Szanton Blanc (eds.), Toward a Transnational Perspective on Migration. New York, New York Academy of Sciences, 1-24.

GOLDEN, Deborah, 2001, “'Now, like real Israelis, let's stand up and sing': teaching the national language to Russian newcomers in Israel”, Anthropology and Education Quarterly, 32 (1): 52-79.

GRIN, Monica, and Michel GHERMAN, 2013, "Cultura judaica e brasileira: uma síntese?", Revista do Instituto Humanitas, 400: 64-68.

GRIN, Monica, and Nelson VIEIRA, 2004, Experiência Cultural Judaica no Brasil: Recepção, Inclusão e Ambivalência. Rio de Janeiro, Top Books.

HALL, Stuart, 1990, "Cultural identity and Diaspora", in Jonathan Rutherford (ed.), Identity: Community, Culture, Difference. London, Lawrence and Wishart, 222-237.

HANDELMAN, Don, and Elihu KATZ, 1990, “State ceremonies of Israel: Remembrance Day and Independence Day", in Don Handelman (ed.), Models and Mirrors: Towards an Anthropology of Public Events. Cambridge, Cambridge University Press, 191-233.

HANNerZ, Ulf, 1996, Transnational Connections: Culture, People, Places. London, Routledge.

HILAL, Jamil, 2015, "Rethinking Palestine: settler-colonialism, neo-liberalism and the individualism in the West Bank and Gaza Strip", Contemporary Arab Affairs, 8 (3): 351-362.

HIMMELFARB, Harold, and Sergio Della PERGOLA (eds.), 1989, Jewish Education Worldwide: Cross-Cultural Perspectives. Lanham, University Press of America.

KATZ, Pearl, 1982, "Ethnicity transformed: acculturation in language classes in Israel", Anthropological Quarterly, 55 (2): 99-111.

KHAZOOM, Aziza, 2001, "Diversity and hybridity in the perceptions of Russians Israelis", Theory and Criticism, 19: 41-44.

KIMMERLING, Baruch, 1985, "Between the primordial and the civil definitions of the collective identity: Eretz Israel or the State of Israel?”, in Erik Cohen, Moshe Lissak and Uri Almagor (eds.), Comparative Social Dynamics: Essays in Honor of S. N. Eisenstadt. Boulder, Westview, 262-283.

KIMMERLING, Baruch, 2008, Clash of Identities: Explorations in Israeli and Palestinian Societies. New York, Columbia University Press.

KUZAR, Ron, 2008, "The term return in the Palestinian discourse on the Right of Return", Discourse and Society, 19 (5): 629-644. 
LERNER, Julia, 2007, “The ethnic script in action: the regrounding of Russian Jewish immigrants in Israel”, Ethos, 35 (2): 168-195.

LESSER, Jeffrey, 1995, Welcoming the Undesirables: Brazil and the Jewish Question. Berkeley, University of California Press.

LEVY, André, and Alex WEINGROD (eds.), 2005, Homelands and Diasporas: Holy Lands and Other Places. Stanford, Stanford University Press.

LOMSKY-FEDER, Edna, and Tamar RAPOPORT, 2001, "Homecoming, immigration, and the national ethos: Russian-Jewish homecomers reading Zionism”, Anthropological Quarterly, 74 (1): 1-14.

MILGRAM, Avraham, 1995, "Precursors of Zionism in Brazil before the turn of the $20^{\text {th }}$ Century”, The Journal of Israeli History, 16 (3): 257-267.

NOY, Chaim, and Erik COHEN, 2005, Israeli Backpackers: From Tourism to Rite of Passage. Albany, State University of New York Press.

ONG, Ahiwa, 1996, "Cultural citizenship as subject making: migrants negotiate racial and cultural boundaries in the United States", Current Anthropology, 37 (5): 737-762.

ORTNER, Sherry B., 2006, "Subjectivity and cultural critique", Vibrant: Virtual Brazilian Anthropology, 3 (1): 37-66.

PAINE, Robert, 1993, "Israel: the making of self in the "pioneering' of the nation", Ethnos, 58 (2): 222-240.

PAPPE, Illan, 2008 "Zionism as colonialism: a comparative view of diluted colonialism in Asia and Africa", South Atlantic Quarterly, 107 (4): 61 1-633.

PAPPE, Illan, 2012, "Shtetel colonialism: first and last impressions of indigeneity by colonized colonizers", Settler Colonial Studies, 2 (1): 39-58.

PAPPE, Illan, 2014, The Idea of Israel: A History of Power and Knowledge. London, Verso.

PELED, Yoav, 1992, "Ethnic democracy and the legal construction of citizenship: Arab citizens of the Jewish state", American Political Science Review, 86 (2): 432 $-443$.

PORTES, Alejandro, and Josh DeWIND (eds.), 2007, Rethinking Migration: New Theoretical and Empirical Perspectives. Oxford, Berghahn.

PORTES, Alejandro, L. GUARNIZO, and P. LANDOLT, 1999, "The study of transnationalism: pitfalls and promise of an emergent research field", Ethnic and Racial Studies, 22 (2): 217-237.

RABINOWITZ, Dan, 1997, Overlooking Nazareth: The Ethnography of Exclusion in Galilee. Cambridge, Cambridge University Press.

REICHARDT, David, 2011, "O sionismo na cidade de São Paulo: uma etnografia contemporânea dos movimentos juvenis sionistas”, Campinas, Programa de Pós-Graduação em Antropologia Social, Instituto de Filosofia e Ciências Humanas, Universidade Estadual de Campinas, projeto de mestrado.

SAÏD, Edward, 1990 [1978], Orientalism. London, Vintage.

SAIID, Edward, 1992 [1979], The Question of Palestine. London, Vintage.

SAND, Shlomo, 2009, The Invention of the Jewish People. London, Verso.

SAND, Shlomo, 2012, The Invention of the Land of Israel. London, Verso.

SHAVIT, Ari, 2014, My Promised Land: The Triumph and Tragedy of Israel. Brunswick and London, Scribe.

SHOHAT, Ella, 1988, "Sephardim in Israel: Zionism from the standpoint of its Jewish victims", Social Text, 19-20: 1-35. 
SHOKEID, Moshe, 1988, Children of Circumstances: Israeli Immigrants in New York. Ithaca, Cornell University Press.

SMITH, Anthony D., 1995, "Zionism and Diaspora nationalism", Israel Affairs, 2 (2): 1-19.

SMOOHA, Sammy, 1997, "Ethnic democracy: Israel as an archetype", Israel Studies, 2 (2): 198-240.

SMOOHA, Sammy, and Yochanan PERES, 1975, "The dynamics of ethnic inequalities: the case of Israel”, Social Dynamics, 1 (1): 63-75.

SORJ, Bernardo, 2008, "Brazilian non-anti-Semite sociability and Jewish identity", in Judith Bokser Liwerant et al. (eds.), Identities in an Era of Globalization and Multiculturalism: Latin America in the Jewish World. Leiden, Brill, 151-170.

SORJ, Bila (ed.), 2008, Identidades Judaicas no Brasil Contemporâneo [e-book]. Rio de Janeiro, Centro Edelstein de Pesquisas Sociais, available from < http://books.scielo.org/id/h9ypr/p df/sorj-9788599662601.pdf > (last access in February 2019).

STEIN, Rebecca, 2010, "Israeli routes through Nakba landscapes: an ethnographic meditation”, Jerusalem Quarterly, 43: 6-17.

TARTAKOVSKY, Eugene, 2010 , "Found in transition: an acculturation narrative of immigration from the former Soviet Union to Israel”, Culture Psychology, 16 (3): 349-363.

VERACINI, L., 2010, Settler Colonialism: A Theoretical Overview. London, Palgrave Macmillan.

VERTOVEC, Steven, 2001, "Transnationalism and identity", Journal of Ethnic and Migration Studies, 27 (4): 573-582.

WEINGROD, Alex (ed.), 1985, Studies in Israeli Ethnicity After the Ingathering. New York, Gordon and Breach.

WOLFE, Patrick, 1999, Settler Colonialism and the Transformation of Anthropology: The Politics and Poetics of an Ethnographic Event. Londres e Nova Iorque, Cassell.

YIFTACHEL, Oren, 1997, "Israeli society and Jewish-Palestinian reconciliation: ethnocracy and its territorial contradictions”, Middle East Journal, 51 (4): 505-519.

YIFTACHEL, Oren, 2006, Ethnocracy, Land and Politics in Israel/Palestine. Philadelphia, University of Pennsylvania Press.

ZERUBAVEL, Yael, 1995, Recovered Roots: Collective Memory and the Making of Israeli National Tradition. Chicago, The University of Chicago Press.

ZUREIK, Elia, 1979, The Palestinians in Israel: A Study of Internal Colonialism. London, Routledge and Kegan Paul.

Receção da versão original / Original version

$2016 / 12 / 12$

Receção da versão revista / Revised version

$2018 / 02 / 23$

Aceitação / Accepted

$2018 / 07 / 25$ 